\title{
Proposal of Acceptable Air Tightness Classes for Buildings in Chile
}

\author{
Propuesta de Clases de Infiltración Aceptables para los Edificios chilenos
}

Ariel Bobadilla M. (Autor Principal)

Universidad del Biobío / Centro de Investigación en

Tecnologías de la Construcción, Chile

abobadil@ubiobio.cl

AvCollao 1202, Concepción, Chile, CP 4051381 / +56-41-2731127

\section{Muriel Díaz C.}

Universidad del Biobío/Centro de Investigación en

Tecnologías de la Construcción, Chile

madiazc@ubiobio.cl
Rodrigo Figueroa S.

Universidad del Biobío/Centro de Investigación en Tecnologías de la Construcción, Chile rfiguero@ubiobio.cl

Roberto Arriagada B.

Universidad del Biobío/Centro de Investigación en Tecnologías de la Construcción, Chile / rarriaga@ubiobio.cl

Código: 0219

Fecha de Recepción: 01.01.2014.

Fecha de Aceptación: 01.04.2014.

\section{Abstract}

In order to limit the energy demands the building ordinances establish requirements for reducing to acceptable levels the energy losses and/or gains. This situation obliges to define acceptable standards for thermal parameters. This report covered the evaluation of representative samples of Chilean homes built in 2007 and 2010 in the 54 provincial capitals of the country. A sample of 191 units was determined, representative of the construction, materials and housing architecture in Chile. Experimental techniques were used (Blower Door test) for obtaining air tightness of samples; numerical models (LBL Model) for relating the air tightness properties with the weather characteristics of every province in order to obtain infiltration coefficient classified by type of construction and province; simulation techniques (Thermal Analysis Simulation Software) for determining the energy demand of housing

The Air Tightness classes are established combining two criteria: the one that measures the current state of air tightness of housings and other that limits the infiltration demand to a limit value that explains itself economically.

Keywords: Air Tightness, Residential Buildings, Energy Efficiency, Infiltration, Class

\section{SCOPE}

Buildings are essential components of society and economy. They offer safe spaces and environments that have thermal protections for the development of human activity. From a purely energy point of view, a building can be conceptualized as a technological product designed and created for supplying services that demand energy and whose construction and operation during its lifetime and following demolition has impacts on the environment. $45 \%$ of the energy produced worldwide is used for heating, cooling, lightening and ventilating buildings. The consequence is that $50 \%$ of global warming is prod87uced by fossil fuels consume in buildings (The Aalborg Commitments, 1994). In Chile the building sector is responsible for $26 \%$ of the final use of energy, for $34 \%$ of production of solid waste, for $33 \%$ of greenhouse gas emissions and for $6 \%$ of water use (Minvu, 2013). As a result, the energy demand of buildings has also important ethic and social dimensions that cannot be omitted.

The legal and political systems in practically all countries require buildings to have socially acceptable performance. This is frequently achieved stating minimum requirements related to objectives of safety, health, energy saving and sustainability among others. The laws usually include these ordinances in norms, technical itemized, regulations or ordinances that are the judicial tools destined to guarantee that the building, once built and in use according to these tools, offers socially acceptable performances for the users and the community (Meacham, B.J., et al., 2002). To do this, it is also essential to make inspections and regulatory controls of design, construction and operation of the building in its different stages.
In practice, establishing minimum requirements of energy performance raises the issue of optimizing the relation between supplying thermal comfort, the energy demand and costs for those purposes. In this context the requirements or basic demands represent specific conditions that must have not only the building design but also its building systems and the materials involved to accomplish the objective of limiting the energy demand. There are two important requirements for this: thermal insulation of the envelope for limiting the transmission, using a $\mathrm{U}$-value $\left(\mathrm{W} / \mathrm{m}^{2} \mathrm{~K}\right)$ and air tightness of the envelope for limiting the convection, using $\mathrm{ACH}$ measurements $(1 / \mathrm{h})$. The acceptable classes summarize these two requirements and what society is willing to accept as maximum energy loss of its buildings.

The need of defining acceptable air tightness classes for housings in Chile encourages the development of the project FONDEF D 10 I 1025 (Chilean Fund to Promote Scientific and Technological Development) executed with the guidance of the Ministry of Housing and Urban Planning (Minvu) and Ministry of Public Works (MOP) by a technology consortium formed by CITEC UBB and DECON UC and a group of associated national firms. The aim of the project - carried out between 2012 and 2014- was to develop air tightness standards and acceptable infiltration classes of buildings according to the region of Chile, in order to reduce to acceptable limits the impact of air infiltration on the demand and energy consumption in the building sector. Additionally a Technology Know How was carried out to support the design, execution and quality control of works for securing buildings with air tightness levels according to the needs of optimal minimum energy use throughout the entire Chilean territory. 
The air tightness is the physical ability of the envelope for resisting air infiltrations. It is expressed and measured through normalized procedures universally accepted. Furthermore, there are classifications in relation to this ability that help to evaluate and compare air tightness among a universe of constructions. However, it does not exist a procedure that allows determining the level of such desired abilities for every region or weather in which the building is located. This should be a construction representative of every country as involves social, cultural and technology aspects specific of every nation and its policies on this matter.

The present report reveals the proposal of air tightness classes for buildings in Chile executed in the frame of the previously cited project. This proposal of classes considers the Standard of Minvu NTM 011/3 2014: Requirements and accreditation mechanisms for climate conditioning of buildings subjected to public consultation on March 2014.

Figure 1.Current measured energy demand for thermal conditioning of a residential building on brickwork in different thermal zones of Chile. Source: Self Elaboration CITEC UBB 2014.

\section{Energy Demand ( $\mathrm{kWh} / \mathrm{m} 2$ year)}

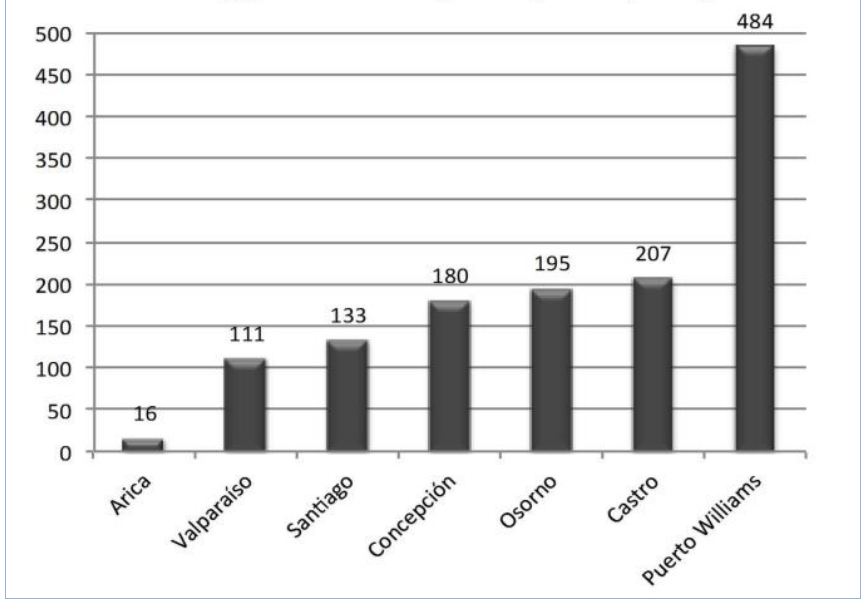

DESCRIPTION OF THE PROBLEM

\section{Energy quality of buildings: problems and challenges}

The demand of useful heat for thermal conditioning of housing in Chile varies visibly with the weather. Therefore a similar variation in energy quality of constructions would be expected. This is not observed though: Figure 1 shows the evolution of energy demand for conditioning of a typical residential building on brickwork, with HAVC service in seven cities of Chile, representative of the thermal zones that define the Thermal Regulation of Chile. The case considers thermal insulation in agreement with the regulatory requirements of every zone and with the air infiltration loads according to the air tightness of this type measured during the Fondef project D10 I 1025.

In those regions with main heating demands, the most significant in the national territory, the energy required to heat residential buildings varies in 133 and $484 \mathrm{~kW}-\mathrm{h} / \mathrm{m}^{2}$ per year, considered today as excessively high. This amount is between $50 \%$ and $200 \%$ higher in the different regions than the quantity it should have if it envelopes had optimal thermal protections, as suggested by multiple studies (Damico et al, 2012; Escorcia et al, 2012; Trebilcock, Celis\&Miotto, 2012).

Figure 1 shows that supplying the same heating services varies significantly depending on the region of the country the house is located. Currently this matter is discussed in Chile: such discrepancies indicate multiple levels of climate rigurosity but also thermal quality levels of constructions that do not correspond to the climate solicitations of every region. There are two critical aspects: the low levels of thermal insulation demanded in Chile and the low ability of constructions for resisting infiltrations.

The thermal insulation standards demanded by the regulation for housings in Chile are not well compared with those of the European ordinances that regulate in similar weather, nor with the standards suggested by several studies in Chile for many decades (Rodríguez, G., 1972; Bobadilla, A. et al., 1986; Bobadilla, A. et al., 1991; Bustamante, W., 2010; D'Alençon, R. 2010; CITEC UBB, 2012a). In the thermal zone 4 -Concepcion as the representative locality- the Thermal Regulation states the maximum thermal transmittance for walls in $1,7 \mathrm{~W} / \mathrm{m}^{2} \mathrm{~K}$. Studies suggest for Concepcion limit transmittances never superior to $1,0 \mathrm{~W} / \mathrm{m}^{2} \mathrm{~K}$ for avoiding building pathologies such as condensation and only because of energy saving in the range of 0,5-0,6 W/m² K (CITEC UBB, 2010a).

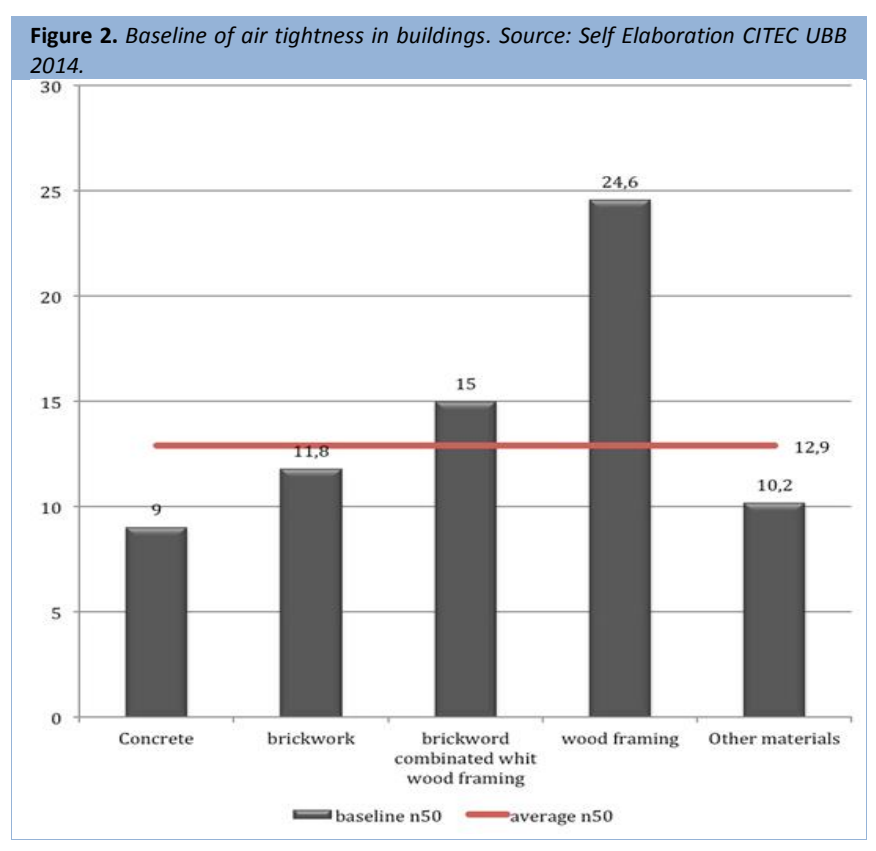

The thermal insulation standards are clearly not adapted to the climate solicitations of every locality. At the same time, they are incompatible with the current needs of optimal minimum energy consumption, particularly in the center-south regions of the country and the most populated ones. In this manner significant differences were observed in the ability of buildings for limiting the energy demand, in other words, in their qualification for use along the different zones. This situation shed lights on the energy quality of the housings in Chile and the existence of different quality breaches according to zones and localities of the country. These gaps should also be shown 
in order to give a better guidance to the Energy Improvement Plans of housings in Chile.

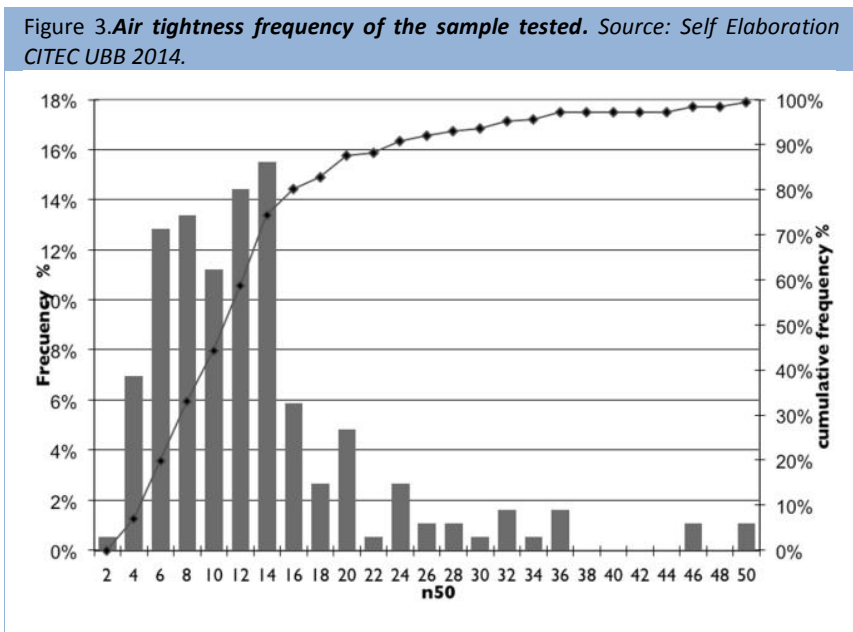

The average air tightness of new housings in Chile (Figure 2), its $\mathrm{n} 50$ value, is at a level of $12,91 / \mathrm{h}$. The expected mean value for dwellings is in the range of 11,1 and 14,7 with a $95 \%$ of confidence level. These values illustrate the air tightness of constructions in Chile, the state of the art of designing and building and they also indicate the energy quality of housings. Less than $5 \%$ of housings could meet the reference standard of $31 /$ h set in various European countries (Figure 3 ). Particularly critical is the standard for wood frame construction, which presents measurements of air tightness around $24,61 / \mathrm{h}$. These indicators represent the absence or poor use of sealing techniques and the low quality of implementation: such aspects should be improved in order to guarantee an acceptable energy performance of that and any other type of construction practiced currently in Chile. Consequently, it is necessary to establish limits to air tightness in constructions in Chile.

\section{Thermal regulations in Chile}

The regulatory framework aimed to achieve socially acceptable performance in residential buildings in Chile is precarious and in development. It is formed by a thermal regulation that rules only for housings, a national technical itemized that regulates only housings of the program Fondo Solidario de la Vivienda (Supportive Housing Fund) and six official standards of obligatory use, feature acquired by standards in Chile only when they are incorporated into documents with force of law: two calculations standards, three test standards and one thermic zonification and design recommendations. Other 24 standards are under study and/or public consultation and it is expected to add it without delay.

In the public edification sphere more progress has been made, because of the nature of the contracts and by the initiative of the Architecture Department (DA) of MOP. The DA MOP developed in 2012 the instrument Standardized Terms of Reference (Términos de Referencia Estandarizados) TDRe on energy efficiency and interior climate quality of public buildings. TDRe are technical guidelines that the MOP started to employ as a pilot in 2013 as an instrument of inspection of the design and work of the climate and energy performance of projects on public building. They define by zone and type of building the requirements, the indicators, the performance criteria (limit values) and the verification procedures of a series of energy and climate requirements along with the verification procedures. This instrument presents thermal insulation and air tightness requirements of buildings according to the demands of minimum energy use, practically the same that are expected to be meet by dwellings.

In the residential construction sphere the Ministry of Housing and Urban Planning added the study of a thermal regulation of housing to its program of action the year 1994 (Minvu, 2002), as a result of reviewing the European experience and the actions primarily promoted by the academic world. Thus in 2000 Chile became the first country of Latin America in adding thermal insulation requirements for housings to the building regulation. High consideration was made at that moment of the impact this decision would have in Chile, country largely dependent on energy and with serious quality problems of its housings.

The development of the regulation was carried out in stages. The first stage, put into action in 2000, regulated the maximum thermal transmittance through the roofs along with establishing a zonification of the territory for purposes of architectonic design. The second stage came into force in 2007 and ruled the maximum thermal transmittance through walls, crawl spaces plenum and maximum area of windows. Finally stage three, which will take effect in 2014 and is of voluntary application only, regulates the global energy performance of the housing through an energy qualification system.

The Chilean regulation, on the contrary to the most developed of Europe, handles only two aspects: territorial subdivision and establishment of thermal insulation standards for components of the envelope. There is no consideration towards the regulation of air tightness in constructions. In other words, an essential element of the energy demand for thermal conditioning of housings that in some cases can represent $60 \%$ is not subjected to regulation or control (CITEC UBB, DECON UC, 2010; Ossio, De Herde, \& Veas, 2012). All the measurements, starting with the establishment of standards, designs, technologies and regulations, have aimed exclusively to reduce losses by transmittance. This situation significantly affects the efficiency and profitability of the actions the industry and the State of Chile undertake to improve the energy quality of its housings. The main challenges the country has nowadays towards the improvement of energy quality of housings are the inclusion of standards for covering factors of thermal comfort, ventilation and air tightness -not currently considered-; the adjustment of thermal insulation standards and the adaptation to the thermal zonification.

In summary, the country shows progress in terms of climate and energy improvement of its buildings, which is important on a Latin-American level, but minor when compared to the global state of the art. In addition, Chile presents asymmetrical developments as essential elements such as air tightness, ventilation and thermal comfort are taken into account as part of the climate and thermal improvement of buildings. The energy efficiency and quality of its buildings is not observed in terms of what the society currently requires: level of technological, social and economy development the country exhibits. 
In countries where air tightness requirements for envelopes exist, multiple verification procedures are carried out such as checklists or pressurization test in order to prove its compliance with the requirements. When test are mandatory, a database that allows making a diagnosis of national housings is obtained for determining those aspects with great influence on energy losses by infiltration and on the interior air quality in order to undertake measurements accordingly (Chan et al., 2012). Most of the countries do not oblige, but provide incentives to perform tests, that is the reason why the databases are still in its infancy (Carrié \& Rosenthal, 2008).

\section{The case of United States}

The database of the US (ResDB) was developed for determining those aspects that influence the air tightness of building envelopes and for diagnosing the building quality of housings. To accomplish this it was considered a sample of 134.000 detached houses in almost all the territory. A regression analysis was used to examine the relation between the normalized leakage and the physical characteristics of housings. The air tightness was expressed as the equivalent leakage area, normalized through elements such as floor area, height and year built, the last one being the most important (Chan et al., 2012).

\section{The case of England}

Due to England is one of the few countries where the execution of pressurization test in new housings is mandatory there are a number of databases of public and private domain. In a study carried out by Pan (2010) of a total of 287 residential housings a $97 \%$ met the standard Part L 1a $2006\left(10 \mathrm{~m}^{3} /\left(\mathrm{h} \mathrm{m}^{2}\right)\right.$. The application of this database aims to serve as an instrument for updating the energy codes, measuring the risks of not compliance of standards, defining the aspects that exist in practice about housing design and building.

\section{The case of Czech Republic}

The database ABD.CZ elaborated in Czech Republic (from 2001 until today) register the results of the measurements taken by the testers group of pressurization test. The tests registered were performed to single-family housings, multi-family housings and office buildings (by the year 2000419 measurements were recorded). Among the data is a description of housings, type of building envelope, type of ventilation, year built, etc.

The purpose of databases is to support the establishment of requirements consistent with the reality of the country (Table 1); to monitor the achieved air tightness levels and its evolution through time; to obtain information on the behavior of air barriers, building systems and general recommendations on good building. From this data is expected to maintain accordingly the air tightness levels demanded by the energy codes (Chan et al., 2012).

\section{Definition of building air tightness standards in Chile}

The methodological approach originates in the criteria used to define the different classes of air tightness internationally. These criteria are based in two aspects: i) the air tightness class of a zone or place should be one that complies with at least a percentage of the housing before setting the standard, and/or ii) the energy load related to infiltration should not exceed a certain limit. Said limit is usually justified based on economic and/or environmental aspects.

In the current Chilean state of knowledge, this research posed the need to conduct several previous studies with the purpose of: a) knowing the baseline of air tightness of the new housing in Chile; b) knowing the normalized or standardized infiltrations of the main types of buildings in every Chilean province to know the real impact of infiltration on the energy demand; and c) designing hourly meteorological databases by the province in Chile, 54 in total.

\begin{tabular}{llc}
$\begin{array}{l}\text { Table 1.Air tightness requirements for building envelopes in housings in different } \\
\text { countries of Europe and North America. Source: Self Elaboration CITEC UBB } 2014 .\end{array}$ \\
\hline Country & Air tightness requirements & $\begin{array}{l}1 / \mathrm{h} @ 50 \mathrm{P} \\
\text { a }\end{array}$ \\
\hline Belgium & $<3 \mathrm{rah} @ 50 \mathrm{~Pa}$ & 3 \\
France & 0,8 a $2.5 \mathrm{~m} 3 / \mathrm{h} / \mathrm{m} 2$ @4Pa & 11 \\
Netherlands & Min. $0.4 \mathrm{rah} @ 10 \mathrm{~Pa}$ y max. $2.24 \mathrm{rah} @$ & 6,5 \\
& $10 \mathrm{~Pa}$. & 4 \\
Norway & $<4 \mathrm{rah} @: 50 \mathrm{~Pa}$. & 2,88 \\
Sweden & $<0.8 \mathrm{I} / \mathrm{s} / \mathrm{m} 2$ & 3,3 \\
Switzerland & $<0.75 \mathrm{~m} 3 / \mathrm{h} / \mathrm{m} 2$ @ 4Pa & 8,3 \\
England & $<10 \mathrm{~m} 3 / \mathrm{h} / \mathrm{m} 2$ @ 50Pa. & 5 \\
\hline EE.UU. & $<3-5 \mathrm{rah} @ 50 \mathrm{~Pa}$ & \\
\hline
\end{tabular}

It is important to note that to calculate the energy demands of housing units and to energetically classify them in Chile the instruments CCLT_CL_V2 and CEV_V_1.0 of the Ministry of Housing and Urban Development are used, which are considered official for this purpose. These instruments contemplate a normalized infiltration value equal to one air renovation per hour, independent of the type of building, geographic place and season of the year. This supposes the same air tightness feature for every building in Chile and the same energy losses due to infiltration for all the buildings in Chile. The previously said is a disadvantage of the instrument that affects its capacity to estimate energy quality, which generates serious misinterpretations in the comparative assessment of quality for the different building technologies. However, advanced simulation software such as TAS, TRNSYS and ENERGY PLUS, that do not have said disadvantage, have always been used assuming air tightness values by default or relatively arbitrarily due to the lack of reliable or at least field based information about the air tightness characteristics of buildings.

The province is chosen as the territorial unit in order to establish the class considering that the main airflow inducing 
mechanisms through the envelope are wind pressures and thermal differentials combined with stack effect and the country's different weather conditions. The territory's physical geography, special orography and topography, and the height and nature of the land generate microclimates and wind regimes that go from almost permanently calm in some locations to nearly extreme situations in some others within the same region. Therefore, determining the province as territorial unit seems to be the most appropriate for the purpose of setting the requirements to define more than one thermal zone. The main constitutive elements of the used methodology are explained below (Figure 4).

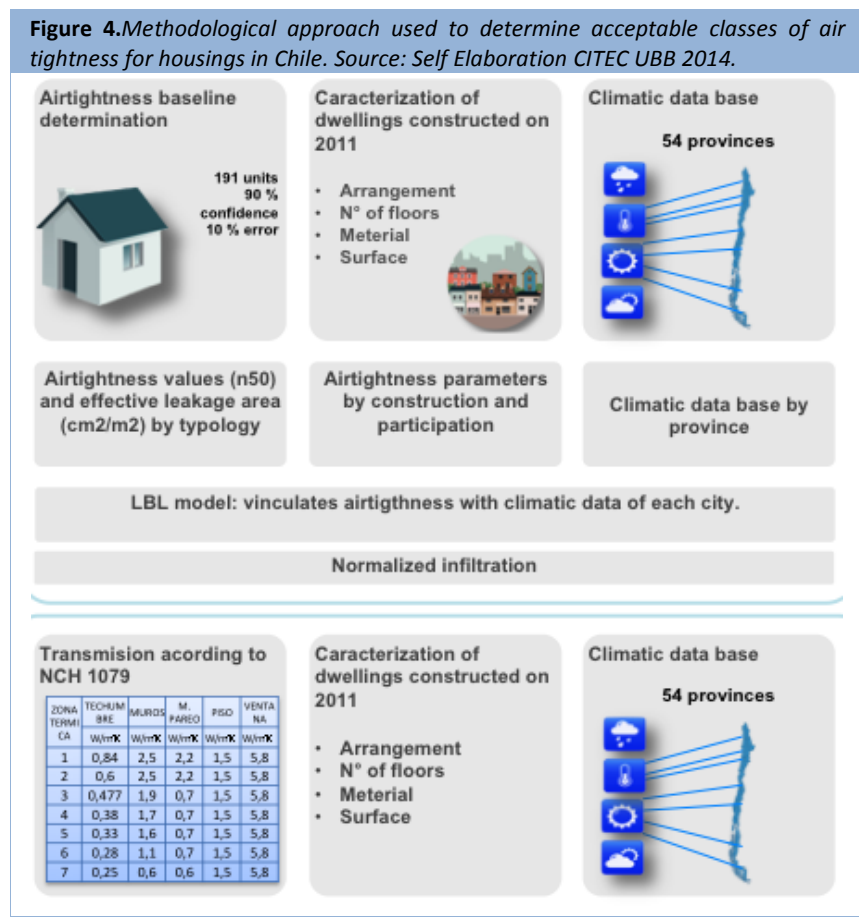

Establishment of air tightness base line

Statistical techniques were used to define and dimension a representative sample of the residential buildings. The population under study to determine baseline air tightness was constituted by the total of registered and authorized residential buildings in the municipalities of Santiago and Concepción in the years 2007 and 2010, according to the Annual Building Report of the National Statistics Institute of Chile (INE, in its Spanish acronym).

The sample's size was 189 buildings: 71 dwellings built in 2007 and 118 in the year 2010, representing more than $95 \%$ of the homes built on those years per constructed area, differentiated by year, kind of material predominant in walls and arrangement.

To determine the air tightness of every unit of the sample the pressurization technique known as Blower-Door Test Method A and B in accordance with the ASTM E779-10 Standard was used. The air tightness indicator used was the $n 50$ value, which expresses the renovations of interior air volume of the building per hour under a differential of $50 \mathrm{~Pa}$.
Finally, statistical techniques were used to determine referential air tightness values for homogenous groups or building types of the population under study.

\section{Sample under study for definition of classes}

The target population consists of every residential building with construction permit requested in year 2011 distributed among the 54 provinces of Chile: a universe of 151,071 housing units, which equals an area of $10,431,888 \mathrm{~m}^{2}$. The observation and sample units for the energy quality study are the building types present in each province, which represent the $80 \%$ of the planned building area for that year. For this purpose a sampling was conducted in base of information directly gathered from the ACCESS database with which the building statistics in Chile were created (Instituto Nacional de Estadisticas, 2011). The typologies are defined on their participation in the target population and on relevant distinguishing characteristics for the purpose of identifying energy quality, such as materiality, number of storeys, average area and grouping. Finally, sets of 20 differentiated types of building present in the 54 provinces of Chile were identified.

\section{Elaboration of weather databases}

In order to determine the energy demand of the dwellings the creation of new weather databases to cover the 54 provinces of Chile was required and the improvement currently available databases. The new ones included hourly information of climatological variables for the 54 provincial capital cities and were obtained by a process of modification and validation of the databases generated by the software Meteonorm (Remund et al., 2013).

The data revision and modification involved the use of the adjustment method used in the University of Southampton (Jentsch, 2013), originally used to correct the effects of global warming on the weather databases. With this methodology it is possible to modify the hourly response of the databases elaborated using Meteonorm to make it correspond to the official monthly information given by the NCh1079 (Instituto Nacional de Normalización, 2008) and other specific local sources (González \& Diaz, 2013).

\section{Determination of normalized infiltrations}

The normalized or standardized infiltration rate links the air tightness, typical of the envelope of every building type, with the local weather variables. It is used to dimension the energy load due to air infiltrations by means of energy simulation softwares. Normalized infiltration indicators are established for the purpose of this study, according to the following criteria:

i) Normalized infiltration indicators of the building obtained with the LBL Model developed in Lawrence Berkley Laboratories (Sherman \& Modera, 1986). These rates are characteristic of a given building type and zone or location where it is placed.

ii) Normalized infiltration indicators by province depending upon the type of building existent in every province and the constructed area. This rate gives a normalized infiltration measurement of the provincial housing as a reflection of the 
normalized infiltrations of the different building types present in the province and their relative participation in the constitution of the housing.

The air tightness traits of the different building types present in every province are taken from the baseline study of the residential buildings.

\section{Housing projects}

Real dwelling architecture was selected to reflect each one of the 20 typologies that serve as models or patterns for the purpose of making energy assessments (Figure 5). The information source were the architectural projects supplied by construction and real estate companies that combined all the current most distinctive characteristics of architecture and housing building technologies offered on the market in the different regions of Chile.

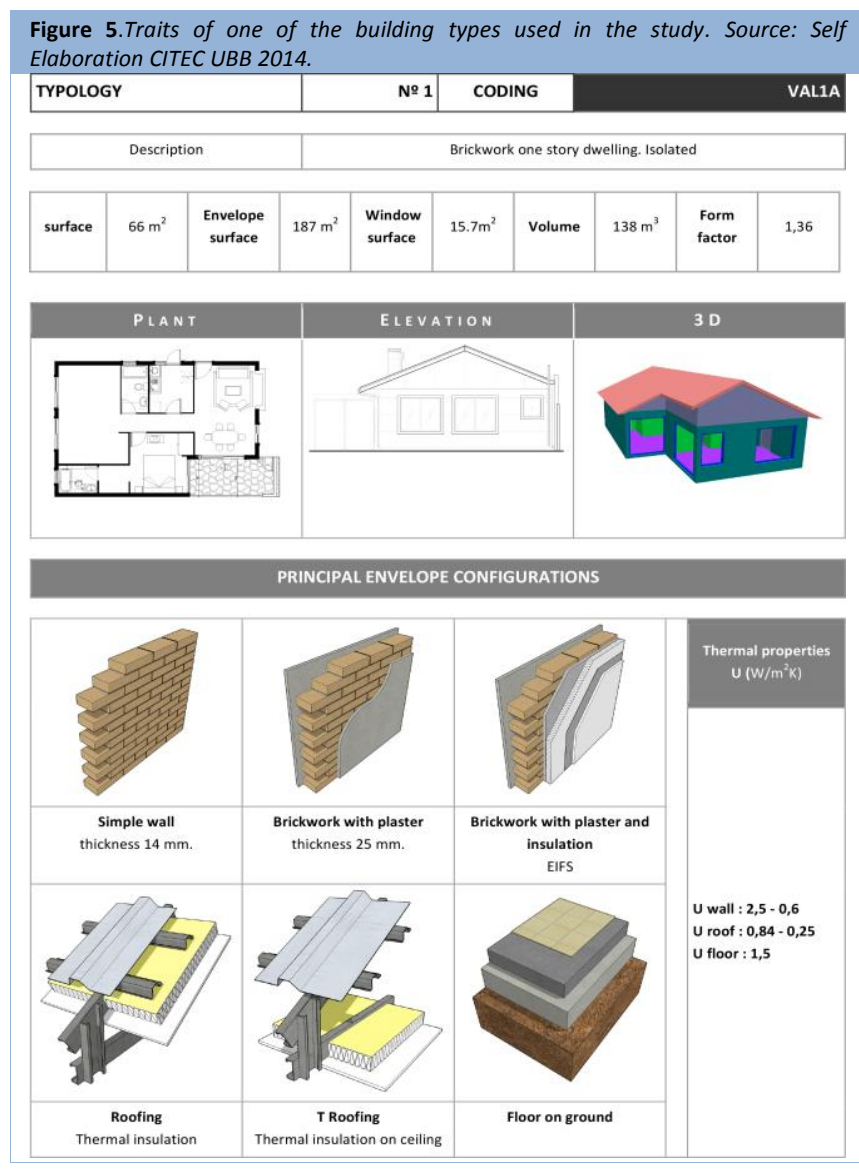

Energy simulations

Simulations of energy performance of buildings were completed on the selected models present in each one of the 54 provincial capitals of Chile with the purpose of evaluating the impact of the different levels of air tightness on the energy demand of each residential building type and on the weighted provincial demand. Additionally, in every province the air tightness was determined linked to $10-20-30-40-50 \mathrm{kWh} / \mathrm{m}^{2}$ year of demand due to infiltration.
The energy assessments were made using the commercial software TAS version 9.2.1.4, universally accepted tool for this purpose. This software uses a multi-zone thermal model to simulate the energy and environmental performance of the building applying a dynamic method. In addition, it allows distinguishing the thermal loads due to air infiltration. Therefore, it is particularly suitable for the purpose of this study.

On Table 1 a summary of the main assumptions and parameters used in the simulation process is shown. The occupation loads, comfort ranges and the HVAC functioning period are the ones used in the thermal behavior certification program for buildings in Chile CCTE V2.0, duly agreed in Chile for this sort of purposes.

Considering the aforementioned assumptions, simulations for the 54 provincial capitals under study were performed. In each city at least two out of the 20 defined typologies were simulated. For each case three different scenarios were simulated: first, a zero infiltration scenario; second, a one air change per hour scenario to represent the currently used energy demand calculations; and third, a scenario that considers the normalized infiltration corresponding to each typology-city combination.

\begin{tabular}{|c|c|}
\hline \multicolumn{2}{|r|}{ InternalGains } \\
\hline Sensible gain & $\begin{array}{l}\text { Monday to Friday : } 30,16 \mathrm{kWh} / \mathrm{m}^{2} \text { day } \\
\text { Saturday toSunday : } 51,6 \mathrm{kWh} / \mathrm{m}^{2} \text { day }\end{array}$ \\
\hline Latentgain & $\begin{array}{l}\text { Monday to Friday: } 19,04 \mathrm{kWh} / \mathrm{m}^{2} \text { day } \\
\text { Saturday to Sunday: } 32,64 \mathrm{kWh} / \mathrm{m}^{2} \text { day }\end{array}$ \\
\hline Lighting & Monday to Sunday:: $39,6 \mathrm{kWh} / \mathrm{m}^{2}$ day \\
\hline Equipments & Monday to Sunday: $39,6 \mathrm{kWh} / \mathrm{m}^{2}$ day \\
\hline \multicolumn{2}{|r|}{ Comfortrange } \\
\hline Allyear & $20-25^{\circ} \mathrm{C}$ \\
\hline \multicolumn{2}{|c|}{ Heating and coolingseasons } \\
\hline Heatingseason & Every month with more than 50 degree day \\
\hline Coolingseason & Every month with more than 50 degree day \\
\hline
\end{tabular}

\section{Definition of classes of air tightness}

The classification by province was established attempting to simultaneously meet the two aforementioned criteria: not to exceed a limit requirement of energy demand and that a percentage of the housing in the province is within the class to be; and to consider the different scenarios that produce the awareness of levels of acceptable air tightness classes and of energy requirements due to infiltration generated by the simulations.

Finally, it is established a $40 \mathrm{kWh} / \mathrm{m}^{2}$ year limit for acceptable infiltration load and a $10 \%$ of observance percentage. These are limit parameters that are simultaneously met in the majority of provinces and where the most of the population is concentrated. The limit values of energy are extracted from real case studies of sealing and air tightness solutions implementation conducted in the context of Fondef Project. The information of classes associated to housing percentages was gathered from the air tightness frequency diagrams elaborated in the study of the air infiltrations baseline in Chile (Figueroa et al., 2013). 
In the provinces where the two criteria are not simultaneously met, cases that occur in southernmost zones and the Andean Plateau, the criterion of maximum energy demand is favored. In these localities the low levels of air tightness in buildings, especially lightweight timber homes, coincide with high wind pressures and low temperatures. These are the zones where the air tightness classes should be much stricter.

\section{RESULTS}

\section{Infiltration coefficient normalized by province}

In Table 2 are presented the normalized infiltration coefficients by province of the new housings registered in year 2011 in Chile. They constitute a measurement of the air tightness class possessed by the building housing registered in 2011 and of the weather features of every province.

In 14 of the 54 provinces the normalized infiltration coefficients are less than or equal to $1(1 / \mathrm{h})$, within the range $0.7-1.0(1 / \mathrm{h})$. They are associated to inland localities, mainly in the centralnorth zone of the country, some of them with microclimates, compatible with average wind speeds under the $2.5 \mathrm{~m} / \mathrm{s}$ and several months of calm winds conditions (less than $2.0 \mathrm{~m} / \mathrm{s}$ ). In some cases these localities coincide also with relatively high average outdoor temperatures that minimize the thermal draught effects. The highest provincial weighted values are within the range of 1 and $2.9(1 / \mathrm{h})$ and are associated with coastal areas, mainly in the central-south zone, with average annual speed above $2.5 \mathrm{~m} / \mathrm{s}$ and/or low average temperatures.

The variations in normalized infiltrations by building type and province are considerably wider and range from $0.4(1 / \mathrm{h})$ for a one story detached building made of concrete block in the northern city of Vallenar (annual average speeds under $2.0 \mathrm{~m} / \mathrm{s}$ and average temperatures of $\left.14.9{ }^{\circ} \mathrm{C}\right)$ to $4.0(1 / \mathrm{h})$ for a one storey detached timber building in the extreme-southern city of Punta Arenas (annual average speed of $8.2 \mathrm{~m} / \mathrm{s}$ and average temperatures of $5.9{ }^{\circ} \mathrm{C}$ ). The extreme case of Punta Arenas is due to the coincidence of extreme weather conditions (mainly because of the high wind speeds) with poor air tightness construction systems (highly permeable to air), such as the current Chilean timber buildings. A completely opposite situation explains the case of Vallenar.

The highest values in Chile are associated with timber construction and the lowest with concrete construction. In the provinces where the impact of infiltration is greater, construction systems with lower air tightness are used. The place where Chile currently presents the lowest air tightness standards are in the central-southern area, where buildings are mainly made of wood framework and different kinds of wooden panels, lightweight construction in general.

\section{Air tightness classes and gaps}

Table 3 shows the acceptable air tightness classes proposal for buildings in Chile. For every provincial capital the desired minimum level of building envelope air tightness is indicated, expressed by the $n 50$ differential pressure value at $50 \mathrm{~Pa}$. The class quantitatively establishes the minimum airtightness target in every province and the specific conditions that the building design and construction process should observe to achieve it.

Because of how it is defined, the class proposal is largely influenced by the deficient current state of air tightness in every province and the existent quality gaps. The acceptable classes vary from $4(1 / h)$ in the most extreme climate provinces to 10 $(1 / \mathrm{h})$ in the most template climate provinces. In five provinces it is not convenient to limit the air infiltrations. These classes should not present difficulties to be observed considering the current technological and economical possibilities in Chile. The classes meet the criterion of not being that strict at the beginning, considering that they are inferior by $50 \%$ in comparison to the international standards.

This new requirements must be progressively modified over time in accordance to a duly scheduled program and the knowledge obtained from them. This should allow an improvement process of the housing's energy quality, which should be sustained over time and monitored with the purpose of measuring its progress

Figure 6 plots different air tightness class references that are useful to note the current state, quality gaps and level of effort needed. The average air tightness is plotted in the current state of housings in every provincial capital, air tightness level or proposed class, level reached by the $10 \%$ of the housing, and the European average air tightness standard, which is around 3 $(1 / h)$.

In the cities with the highest air tightness requirements it can be observed that the best $10 \%$ standard of the housing has energy demands due to infiltrations higher than the established $40 \mathrm{kWh} / \mathrm{m}^{2}$ year, cases that are presented in 11 of the 54 provinces, most of them in the extreme south of the country, where the timber constructions are predominant and the coldest climates of Chile occur. In those provinces the air tightness class is determined by the established energy demand limit and the gaps in those localities are rather significant.

Nonetheless, it is possible to achieve the airtightness performance in every province through design and construction strategies adapted to the class requirements in every province. This has been proven through different experiences carried out in the context of the FONDEF D10 I 1025 Project and reported in Bobadilla et al., 2014.

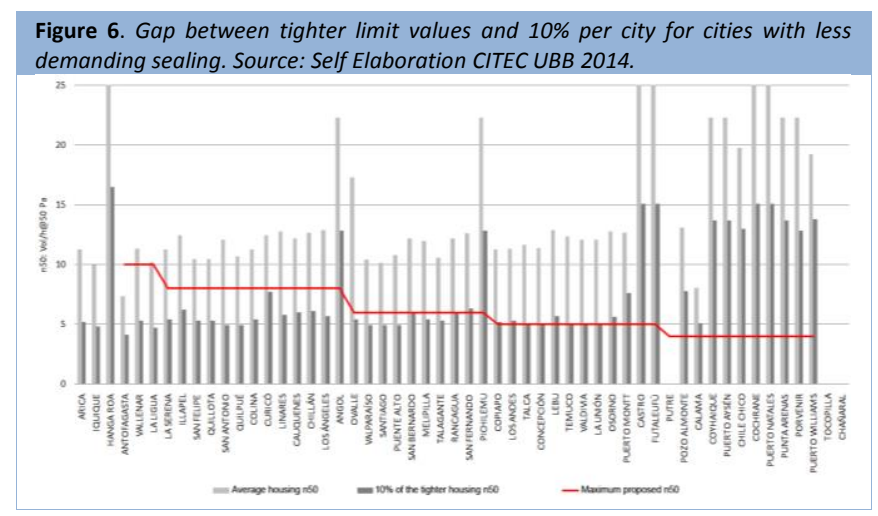


Table 3.Housing's air tightness limits by province: air tightness that does not exceed los $40 \mathrm{kWh} / \mathrm{m}^{2}$ per year, currently achieved by $10 \%, 20 \%$ of the housing and limit value by province. Source: Self Elaboration CITEC UBB 2014.

\begin{tabular}{|c|c|c|c|c|}
\hline City & $\begin{array}{c}\text { n50 límit for } \\
40 \\
\text { kWh/m²year } \\
(1 / \mathrm{h})\end{array}$ & $\begin{array}{c}\text { n50 for } \\
10 \% \\
\text { housing } \\
(1 / \mathrm{h})\end{array}$ & $\begin{array}{c}\text { n50 } \\
\text { limitproposed } \\
(1 / h)^{1}\end{array}$ & $\begin{array}{c}\text { Energy } \\
\text { demand } \\
\text { by } \\
\text { infiltration } \\
\text { for the } \\
\text { proposed } \\
\text { class } \\
\mathrm{kWh} / \mathrm{m}^{2}\end{array}$ \\
\hline Arica & - & 5,2 & -2 & - \\
\hline Putre & 7,5 & -3 & 4 & 22 \\
\hline Iquique & - & 4,8 & -2 & - \\
\hline PozoAlmonte & 5,6 & 7,8 & 4 & 29 \\
\hline Tocopilla & - & -3 & -2 & - \\
\hline Calama & 3,5 & 5,1 & 4 & 46 \\
\hline Antofagasta & 16,1 & 4,1 & 10 & 27 \\
\hline Chañaral & - & -3 & -2 & - \\
\hline Copiapó & 7,8 & 5,2 & 5 & 29 \\
\hline Vallenar & 33,6 & 5,3 & 10 & 13 \\
\hline La Serena & 16,2 & 5,4 & 8 & 21 \\
\hline Ovalle & 13,7 & 13,7 & 6 & 12 \\
\hline Illapel & 23,0 & 6,2 & 8 & 14 \\
\hline La Ligua & 30,0 & 4,7 & 10 & 4 \\
\hline Los Andes & 7,4 & 5,3 & 5 & 28 \\
\hline San Felipe & 17 & 5,3 & 8 & 20 \\
\hline Quillota & 18,6 & 5,3 & 8 & 18 \\
\hline Valparaíso & 8,7 & 4,9 & 6 & 28 \\
\hline San Antonio & 17,8 & 4,9 & 8 & 18 \\
\hline HangaRoa & - & 16,5 & -2 & - \\
\hline Quilpué & 15,3 & 4,9 & 8 & 21 \\
\hline Colina & 11,6 & 5,4 & 8 & 28 \\
\hline Santiago & 7,6 & 4,9 & 6 & 32 \\
\hline Puente Alto & 10,6 & 4,9 & 6 & 23 \\
\hline San Bernardo & 9,9 & 6 & 6 & 25 \\
\hline Melipilla & 16,9 & 5,4 & 6 & 14 \\
\hline Talagante & 9,1 & 5,3 & 6 & 27 \\
\hline Rancagua & 20,7 & 6 & 6 & 30 \\
\hline San Fernando & 21,3 & 6,3 & 6 & 36 \\
\hline Pichilemu & 12,8 & 12,8 & 6 & 11 \\
\hline Curicó & 20,3 & 7,7 & 8 & 17 \\
\hline Talca & 14,7 & 5,1 & 5 & 14 \\
\hline Linares & 19,3 & 5,8 & 8 & 18 \\
\hline Cauquenes & 9,8 & 6 & 8 & 33 \\
\hline Chillán & 19,4 & 6,1 & 8 & 17 \\
\hline Los Ángeles & 19 & 5,7 & 8 & 18 \\
\hline Concepción & 8,3 & 5 & 5 & 24 \\
\hline Lebu & 9,4 & 5,7 & 5 & 22 \\
\hline Angol & 32,5 & 12,8 & 8 & 11 \\
\hline Temuco & 12,7 & 4,9 & 5 & 16 \\
\hline Valdivia & 18,1 & 5 & 5 & 11 \\
\hline La Unión & 21,4 & 5 & 5 & 10 \\
\hline Osorno & 16,9 & 5,6 & 5 & 13 \\
\hline Puerto Montt & 9,2 & 7,6 & 5 & 22 \\
\hline Castro & 18,1 & 15,1 & 5 & 12 \\
\hline Futaleufú & 30,3 & 15,1 & 5 & 7 \\
\hline Coyhaique & 5 & 13,7 & 4 & 32 \\
\hline Puerto Aysén & 7,2 & 13,7 & 4 & 23 \\
\hline Chile Chico & 11,5 & 13 & 4 & 14 \\
\hline Cochrane & 8,7 & 15,1 & 4 & 19 \\
\hline PuertoNatales & 8,2 & 15,1 & 4 & 20 \\
\hline Punta Arenas & 3 & 13,7 & 4 & 53 \\
\hline Porvenir & 9,5 & 12,8 & 4 & 17 \\
\hline PuertoWilliams & 4 & 13,8 & 4 & 41 \\
\hline
\end{tabular}

${ }^{1}$ Class verified by NCh3295: 2013, "Determination of the rate of air leakage through the fan pressurization method" excluding (sealing) ventilation devices.

${ }^{2}$ Infiltration is not limited.

${ }^{3}$ There are insufficient data for the prevailing materiality walls.

\section{CONCLUSIONS AND DISCUSSION}

The wide range of buildings in Chile has a reduced capacity to limit the energy demand for thermal conditioning. This phenomenon is greatly attributed to the low thermal insulation standards contemplated in the current regulations and the lack of guidelines focused on limiting air infiltration.

Both the thermal zoning and the insulation requirement standards do not seem to be adjusted to the needs of optimal minimum energy use and must be modified. The quality levels of energy efficiency currently exhibited by the dwelling do not meet the requirements of modern societies, or at least not to the present level of economical and technological development that Chile is experiencing. The excessive air infiltrations that affect the buildings in a considerable extent of the national territory are the cause of a great part of the problem.

The class proposal has been established partly following the universally accepted methods for this kind of work. The proposed classes are not so hard to apply considering the present technological and economical possibilities existing in Chile. The classes meet the criterion of being firstly flexible: they are at an average 50\% inferior considering international requirements standards. Consequently, they must be progressively modified over time according to a duly scheduled program based on the knowledge generated from this experience. This should allow an improvement process of the housing energy quality, process that should be sustained over time and monitored with the purpose of measuring its progress.

The present study, mandated by The MINVU and the Minister of Public Works, combined the use of energy simulation techniques with experimental field assessments to a largerthan-ever-seen scale in Chile. Moreover, it allowed to achieve three intermediate results that were necessary to establish the air tightness classes in Chile, a task of great value to support the process of energy quality improvement of the housing in the country, namely: i) the air tightness baseline of the buildings as first air tightness measure in Chile, which is useful to establish references for the evaluation of policies and programs for air tightness improvement of the housing, to construct quality judgments about the main types of buildings, to establish their causes and define improvement strategies; ii) the normalized or standardized infiltrations of the main typologies of dwellings by province, useful to establish the real energy demand of the residential buildings considering the real impact of air infiltrations, something that could never be accomplished in Chile before; and iii) a meteorological database with hourly information of the 54 provincial capitals of Chile which allows to differentiate the climate particular conditions in every province, useful for the purposes of energy performance studies of buildings throughout the entire national territory.

The results of this study make necessary to establish requirements for the air tightness of residential buildings in Chile as soon as possible, and the same should be adopted for services buildings, which according to air tightness measurements performed in the context of the same Fondef D10 I 1025 Project, exhibit a very similar behavior. Albeit, it is estimated that greater efforts should be made to confirm this situation. 


\section{ACKNOWLEDGEMENTS}

The authors would like to thank the support of CONICYT Chile (National Commission for Scientific and Technological Research) through the Fondef D10 I 1025 Project Establishment of Acceptable Building Infiltration Classes for Chile.

\section{REFERENCES}

Bobadilla A.; Goycoolea, F.; Saelzer (1986). Calidad térmica de la vivienda y su incidencia en las condiciones de habitabilidad. Anales III Semana de la Energía. Universidad de la Frontera. Temuco.

Bobadilla A.; Goycoolea F.; Saelzer G.; Hempel R.; García, R. (1991). Aislación térmica de muros de albañilería y madera. Actas II Seminario de Investigación. Universidad del Bío-Bío, Chillán (1991).

Bobadilla A.; Arriagada, R.; Figueroa R.; Muños C.; Espinoza R.; Díaz M.; Trebilcock M.; Fritz A.; Fookes J. (2014). Manual de hermeticidad al aire de edificaciones. Concepción.

Bustamante, W. (2010). Eficiencia energética en vivienda social: un desafío posible. Camino al Bicentenario Propuestas para Chile. Santiago, Chile: Ediciones Universidad Católica de Chile.

Carrié, F.R., Rosenthal, B. 2008. An overview of national trends in envelope and ductwork airtightness, AIVC Information Paper VIP 29, August 2008, 6 pp., http://www.aivc.org/medias/pdf/Free_VIPs/VIP29_Airtightness.pdf accessed on 01.01.2014

Chan, W. R., RemiCarrié, F., Novák, J., Litvak, A., Richieri, F., Solcher, O., Emmerich, S. J. (2012). Technical Note AIVC 66: Building air leakage databases in energy conservation policies: analysis of selected initiatives in 4 European countries and the USA (p. 24).

CITEC-UBB. (2012) a. Manual de Diseño Pasivo y Eficiencia Energética de Edificios Públicos. Santiago: IC / DA MOP.

CITEC UBB \& DECON UC. (2010). Establecimiento de clases de infiltración aceptable de edificios para Chile. XVIII Concurso de Proyectos de Investigación y Desarrollo. Santiago. CONICYT.

Damico, F. C., Alvarado, R. G., Bruscato, U., Kelly, M. T., Oyola, O. E., \& Diaz, M. (2012). Análisis energético de las viviendas del centro-sur de Chile. Arquitectura Revista, 8(1), 62-75. doi:10.4013/arq.2012.81.07.

D'Alençon, R. (2010). Parámetros y estándares de habitabilidad: calidad en la vivienda, el entorno inmediato y el conjunto habitacional. En Camino al Bicentenario Propuestas para Chile. Santiago de Chile.

Escorcia, O., García, R., Trebilcock, M., Celis, F., \&Miotto, U. (2012). Mejoramientos de envolvente para la eficiencia energética de viviendas en el centro-sur de Chile. Informes de la Construcción, 64(000). doi:10.3989/ic.11.143.
Figueroa, R., Bobadilla, A., Besser, D., Diaz, M., Arriagada, R., \& Espinoza, R. (2013). Air infiltration in Chilean housing: A baseline determination. In W. Lang (Ed.), PLEA 2013 Munich: Sustainable Architecture for a Renewable Future. Munich: Fraunhofer IRB Verlag.

González, A., \& Diaz, M. (2013). Función e impacto del archivo climático sobre las simulaciones de demanda energética. Habitat Sustentable, 3(2), 75-85. Retrieved from http://revistahabitatsustentable.cl/inicio.html

IRCC, (1988). The Inter-jurisdictional Regulatory Collaboration Committeel RCC. Guía para la introducción de códigos de la edificación basados en prestaciones. 118 p , 1988.

Instituto Nacional de Estadísticas. (2011). Informe anual 2011 (p. 138). Santiago de Chile.

Instituto Nacional de Normalización. (2008). NCH 1079 Arquitectura y Construcción- Zonificación climático habitacional para Chile y recomendaciones para el diseño arquitectónico.

Jentsch,M., James ,P., Bourikas, L., \&Bahaj, A. (2013) Transforming existing weather data for worldwide locations to enable energy and building performance simulation under future climates, Renewable Energy, Volume 55(1), pp 514-524.

Ministerio de Vivienda y Urbanismo. (2002). Manual del usuario CCTE_CL (primera ed., p. 32). Santiago de Chile.

Meacham, B.J., Tubbs, B., Bergeron, D., and Szigeti, F. (2002).Performance System Model - A Framework for Describing the Totality of Building Performance, Proceedings of the 4th International Conference on Performance-Based Codes and Fire Safety Design, SFPE, Bethesda, MD, pp.63-77.

Ministerio de Vivienda y Urbanismo. (2013). Estrategia Nacional de Construcción sustentable 2013 - 2020. Ministerio de Vivienda y Urbanismo de Chile, Santiago.

Pan, W. (2010). Relationships between air-tightness and its influencing factors of post-2006 new-build dwellings in the UK. Building and Environment, 45(11), 2387-2399. doi:10.1016/j.buildenv.2010.04.011

Ossio, F., De Herde, A., \& Veas, L. (2012). Exigencias europeas para infiltraciones de aire: Lecciones para Chile. Revista de La Construcción, 11(1), 54-63.

Remund, J., Müller, S., Kunz, S., Hugenin-Landl, B., Schmid, C., \&Schilter, C. (2013). Handbook Part I: Software. In Meteonorm Handbook (p. 55). Bern, Switzerland: Meteotest.

Rodríguez, G. (1972). El clima chileno y su relación con la construcción habitacional. Revista del IDIEM, Vol. 11 (3),163-184..

Sherman, M.H. and Modera, M.P., 1986, Comparison of Measured and Predicted Infiltration Using the LBL Infiltration Model, Proceedings Measured Air Leakage of Buildings, ASTM STP 904 ASTMS, Philadelphia, ASTM, pp. 325-347.

The Aalborg Commitments, (1994). Los compromisos de Aalborg: Carta de las Ciudades Europeas hacía la Sostenibilidad. Conferencia Europea sobre Ciudades Sostenibles, Aalborg, Dinamarca, mayo de 1994. 